$\begin{aligned} & \text { Australian Journal of } \\ & \text { Crop Science }\end{aligned}$
AJCS 14(01):51-63 (2020)

doi: 10.21475/ajcs.20.14.01.p1782

\title{
Root traits and carbon input by sweet sorghum genotypes differs in two climatic conditions
}

\author{
Ibrahim. A. M. Ahmed ${ }^{1}$, Ibrahim Ortaş ${ }^{1 *}$, Celal Yucel ${ }^{2}$, Abdullah Oktem $^{3}$, Derya Yucel ${ }^{2}$, Md Toufiq Iqbal $^{1,4^{*}}$ \\ ${ }^{1}$ Department of Soil Science and Plant Nutrition, University of Cukurova, Adana, Turkey \\ ${ }^{2}$ Eastern Mediterranean Agriculture Research Institute, Adana, Turkey \\ ${ }^{3}$ University of Harran, Department of Field Crops, Faculty of Agriculture, SanliSanlıurfa, Turkey \\ ${ }^{4}$ Department of Agronomy and Agricultural Extension, University of Rajshahi, Rajshahi 6205, Bangladesh
}

*Corresponding author: toufiq_iqbal@yahoo.com

\begin{abstract}
Response of sweet sorghum [Sorghum bicolor (L.) Moench] root traits and carbon (C) input under two different climatic condition is not well understood. The aims of this study were to characterize and compare root biomass and root traits of several sweet sorghum genotypes at field condition and to estimate their $\mathrm{C}$ input to into soil. Roots and shoots were analyzed for $\mathrm{C}$ concentration and $\mathrm{CO}_{2}$ was calculated. Root samples were collected through monolith root sampling techniques. Root morphological characteristics like root surface area and root volume were differed between locations as well as locations $\times$ genotypes interactions. Root surface area varies from 423,800 to $887,800 \mathrm{~m}^{2} \mathrm{ha}^{-1}$ in Mediterranean soil and 339,100 to $579,600 \mathrm{~m}^{2} \mathrm{ha}^{-1}$ for Harran soil. All sweet sorghum genotypes inputs root and shoot $\mathrm{C}$ as well as $\mathrm{CO}_{2}$ higher in Mediterranean than Harran soil. Root C input varies from 140 to $386 \mathrm{Mg}^{-1}$ in Mediterranean soil and 112 to $224 \mathrm{Mg} \mathrm{ha}^{-1}$ for Harran soil. A greater diversity of root traits was found on several sweet sorghum genotypes irrespective to plant biomass $C$ inputs into the soil. However, compared to several sweet sorghum genotypes, their lower $C$ input to soil needs to be recognized to ensure a balanced $\mathrm{C}$ budget. This study concluded that several sweet sorghum genotypes can be a good source of soil $\mathrm{C}$ sequestration under different climatic conditions of Turkey.
\end{abstract}

Keywords: Root morphology, $\mathrm{C}$ budget, $\mathrm{C}$ sequestration, Root and shoot $\mathrm{C}$, Root and shoot $\mathrm{CO}_{2}$. Abbreviations: $\mathrm{C}=$ Carbon, $\mathrm{CO}_{2}=$ Carbon di oxide

Introduction

Sweet sorghum [Sorghum bicolor (L.) Moench] are annual crops from which the sweet sap can be fermented to ethanol (Bernardes et. al., 2015). Sweet sorghum is a $C_{4}$ crop in the grass family and is characterized by its high photosynthetic efficiency (Sage, 2004). Sweet sorghum can also adapt a wide range of climatic and soil conditions (Wu et. al., 2010). Sweet sorghum cultivation and practices are simple and readily adoptable (Almodares et. al., 1997). Sweet sorghum is also a short day plant and most varieties require fairly high temperature to make their best growth (Mamoun and Salma, 2015).

Since studying root morphology is time-consuming and labor intensive (Costa et al., 2002; Dowdy et. al., 1998; Monti and Zatta, 2009; Nickel et. al., 1995). Little information exists on root morphological characteristics of sweet sorghum particularly under diverse field experimental conditions. Besides their role in nutrient uptake, roots constitute a major source of carbon (C) for soil (Rasse et. al. 2005) and root biomass might be a good indicator of crop $C$ input to soil
(Monti and Zatta, 2009). Soils contain the largest amount of C in the terrestrial ecosystem with roughly twice the amount of C stored in the soil as found in the atmosphere (Batjes, 1996; Powlson et. al., 2011). Sweet sorghum produces a net $C$ flux from the soil to the atmosphere (Le Quéré et al., 2012). It is essential to estimate the ability of the soil to sequester $C$ back from the atmosphere (Schulp et. al., 2008) and to mitigate the emissions of $\mathrm{CO}_{2}$ into the atmosphere. Increasing soil carbon may play a critical role in mitigating $\mathrm{CO}_{2}$ emissions. Consequently, relatively small changes to the soil $\mathrm{C}$ pool can influence the global C balance (McNally et al., 2015).

Little information exists on root morphological characteristics of sweet sorghum [Sorghum bicolor (L.) Moench] crops under field conditions, which can be a major determinant of $C$ input to soil (Thivierge et. al., 2016). Our previous study evaluated dry weight and nutrient uptake of twenty one sweet sorghum genotypes grown in two separate locations of Turkey (Ibrahim et al., 2018). However, the influence of weather variation on root traits and carbon input by sweet sorghum genotypes is 
poorly understood for Mediterranean and Harran soil. The purpose of the experiment was to screen the most suitable sweet sorghum genotypes or lines with root biomass production and their $C$ input into the soil. We hypothesized that several sweet sorghum genotypes will be helped to accumulate $\mathrm{C}$ in soil.

\section{Results}

\section{Sweet sorghum genotypes growth response}

Sweet sorghum genotypes growth response varied differently irrespective to year and genotypes (Table 3). Plant height was higher in Sanliurfa than Adana location. The plant height varies 325 to $427 \mathrm{~cm}$ in the year 2016 at Adana location. Similarly, the plant height varies 313 to $425 \mathrm{~cm}$ in the year 2017 in same location. The plant height varies 352 to $446 \mathrm{~cm}$ in Sanliurfa location for the year 2016. Similarly, plant height varies 333 to $423 \mathrm{~cm}$ in Sanliurfa location for the year 2017. On average, shoot dry weight was higher in 2016 than 2017 in both locations. The shoot dry weight of several genotypes varies 29048 to 49175 and 31905 to $65011 \mathrm{~kg} / \mathrm{ha}$ in the year 2016 and 2017 respectively in Adana location. The shoot dry weight varies 29968 to 42762 and 31683 to $54000 \mathrm{~kg} / \mathrm{ha}$ in the year 2016 and 2017 respectively in Sanliurfa location. In general, root dry weight was higher in 2016 than 2017 for several sweet sorghum genotypes in Adana location. The root dry weight of several sweet genotypes varies 5510 to $8118 \mathrm{~kg} / \mathrm{ha}$ in the year 2016 in Adana location. Similarly, the root dry weight of several sweet sorghum genotypes varies 5273 to $7875 \mathrm{~kg} / \mathrm{ha}$ in the year 2017 in Adana location. The root dry weight varies 4512 to 7115 and 5119 to $7579 \mathrm{~kg} / \mathrm{ha}$ in the year 2016 and 2017 respectively for Sanliurfa location.

\section{Root morphological characteristics}

Root morphological characteristics of several sweet sorghum genotypes vary among the genotypes and locations to locations. The root length of several sweet sorghum genotypes was higher in Şanlıurfa than Adana location except Nebraska sugarcane, P1579753, Wray, BATAEM-4 and Gülşeker genotypes (Table 4). The highest root length was found 235366 $\mathrm{km} \mathrm{ha}^{-1}$ for Cowley sweet sorghum genotypes and lowest root length was found $139310 \mathrm{~km} \mathrm{ha}^{-1}$ in Nebraska Sugarcane sweet sorghum genotypes at Şanlıurfa location.

Root surface area of several sweet sorghum genotypes was higher in Adana than Şanlıurfa except Cowley sweet sorghum genotypes except Cowley sweet sorghum genotypes (Table 4). The highest root diameter was $0.75 \mathrm{~mm}$ for P1579753 sweet sorghum genotype and lowest root diameter were found 0.54 $\mathrm{mm}$ for UNL-hybrid-5, Wary and Smith sweet sorghum genotypes at Şanlıurfa location.

Root diameter differ significantly $(P \geq 0.05)$ among sweet sorghum genotypes (Table 4). However, locations as well as locations and genotypes interaction did not differ irrespective to root diameter of several sweet sorghum genotypes. The highest root diameter was found $0.68 \mathrm{~mm}$ for White Orn and lowest was $0.49 \mathrm{~mm}$ for $\mathrm{P} 1579753$ sweet sorghum genotypes at Adana locations.

Interestingly, root volume differs significantly $(P \geq 0.05)$ between locations, among genotypes as well as locations and genotypes interactions (Table 5). The highest and lowest root volume for Wary and UNL-hybrid-5 sweet sorghum genotypes were 26.70 and $8.46 \mathrm{~m}^{3} \mathrm{ha}^{-1}$ respectively at Adana location. Likewise, the highest and lowest root volume for Wary and UNL-hybrid-5 sweet sorghum genotypes were 20.8 and 7.88 $\mathrm{m}^{3}$ ha-1 $^{-1}$ respectively at Şanlıurfa location (Table 4).

\section{Root C input in several sweet sorghum genotypes}

Root $C$ input was higher in Adana than Şanlıurfa locations (Figure $1 \mathrm{a}$ and Figure $1 \mathrm{~b}$ ). The root $C$ input was higher in 2016 than 2017 in Adana location. The root C input varies 2616 to 4027 and 2275 to $3582 \mathrm{~kg} / \mathrm{ha}$ in the year 2016 and 2017 respectively in Adana location (Figure 1a). Root $\mathrm{C}$ input varies 2217 to 3400 and 2290 to $3631 \mathrm{~kg} / \mathrm{ha}$ in the year 2016 and 2017 respectively in Sanliurfa locations (Figure 1b).

Sweet sorghum genotypes root $C$ inputs differ significantly $(P \geq 0.05)$ between locations as well as locations $\times$ genotypes interactions. However, root $C$ inputs did not differ among several sweet sorghum genotypes (Table 5 ). The highest root $\mathrm{C}$ input was found $386 \mathrm{Mg} \mathrm{ha}{ }^{-1}$ in Wary sweet sorghum genotypes and lowest root $\mathrm{C}$ input was found $140 \mathrm{Mg} / \mathrm{ha}$ in UNL-hybrid-5 at Adana location. Likewise, the highest root $C$ input was $224 \mathrm{Mg} /$ ha for P1579753 sweet sorghum genotypes and lowest root $C$ input was found $112 \mathrm{Mg} / \mathrm{ha}$ in smith sweet sorghum genotypes.

\section{Shoot $C$ input in several sweet sorghum genotypes}

In general, two year average shoot $\mathrm{C}$ inputs were double in Adana locations than Şanlıurfa locations with some exceptions (Figure 2). Shoot $C$ inputs significantly $(P \geq 0.001)$ differed between two locations. However, the shoot $C$ inputs did not differ among genotypes as well as locations $\times$ genotypes interaction (Table 5). The highest shoot $C$ input was found $3334 \mathrm{Mg} / \mathrm{ha}$ for BATAEM-4 sweet sorghum genotypes and lowest shoot C was found $1007 \mathrm{Mg} /$ ha for UNL-hybrid-5 genotypes at Adana locations. However, shoot $\mathrm{C}$ input varies 1014 to $1923 \mathrm{Mg} / \mathrm{ha}$ in several sweet sorghum genotypes at Şanlıurfa locations.

\section{Root Carbon content converted into $\mathrm{CO}_{2}$}

After analyzing the root carbon content, total carbon dioxide was calculated. It seems that root carbon fixation was higher in Adana location than Şanlıurfa location except M81-E and P1579753 sweet sorghum genotypes (Figure 3). Root $\mathrm{CO}_{2}$ fixation did not differ among genotypes. However, root fixed $\mathrm{CO}_{2}$ differ between locations as well as locations $\times$ genotypes interaction (Table 6). The maximum root $\mathrm{CO}_{2}$ was found 1417 $\mathrm{Mg} /$ ha for Wary sweet sorghum genotypes and minimum was found $515 \mathrm{Mg} / \mathrm{ha}$ for UNL-hybrid-5 sweet sorghum genotypes for Adana location. Similarly, the maximum root fixed $\mathrm{CO}_{2}$ was 
Table 1. Some Chemical and physical properties of soil at depths of 0-30 cm in Adana and Şanlıurfa Location.

\begin{tabular}{lcc}
\hline Location & Adana & Şanlıurfa \\
\hline $\mathrm{pH}\left(1: 2.5 \mathrm{H}_{2} \mathrm{O}\right)$ & 7.40 & 7.6 \\
$\mathrm{EC}(\mathrm{dS} / \mathrm{m})\left(1: 2.5 \mathrm{H}_{2} \mathrm{O}\right)$ & 0.18 & 0.2 \\
$\mathrm{OM}(\%)$ & 1.16 & 0.67 \\
Total N (\%) & 0.11 & 0.059 \\
Available P $(\mathrm{mg} / \mathrm{kg})$ & 0.63 & 0.39 \\
$\mathrm{CaCo3}(\%)$ & 30.3 & 40.8 \\
Sand $(\%)$ & 25.2 & 28.3 \\
Silt $(\%)$ & 42.0 & 26.7 \\
Clay $(\%)$ & 32.8 & 45.0 \\
Textural class & clay loam & clay \\
\hline
\end{tabular}

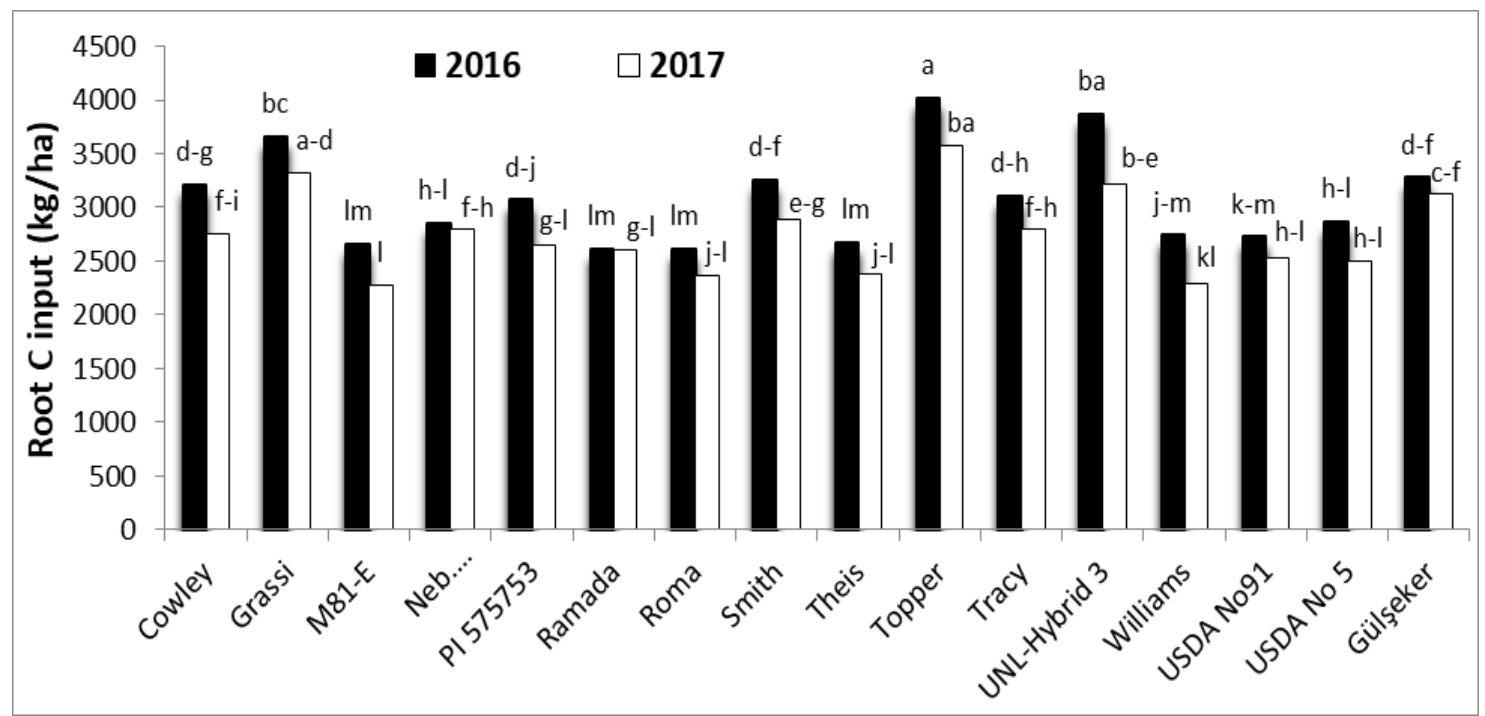

Fig 1a. Root $\mathrm{C}$ inputs in several sweet sorghum genotypes at a depth of 0-30 cm for Mediterranean soil ( Adana location). Data were means of three replicates. Means followed by the same letter within a column are not significantly differed at $\mathrm{P} \geq 0.05$ based on the Tukey test.

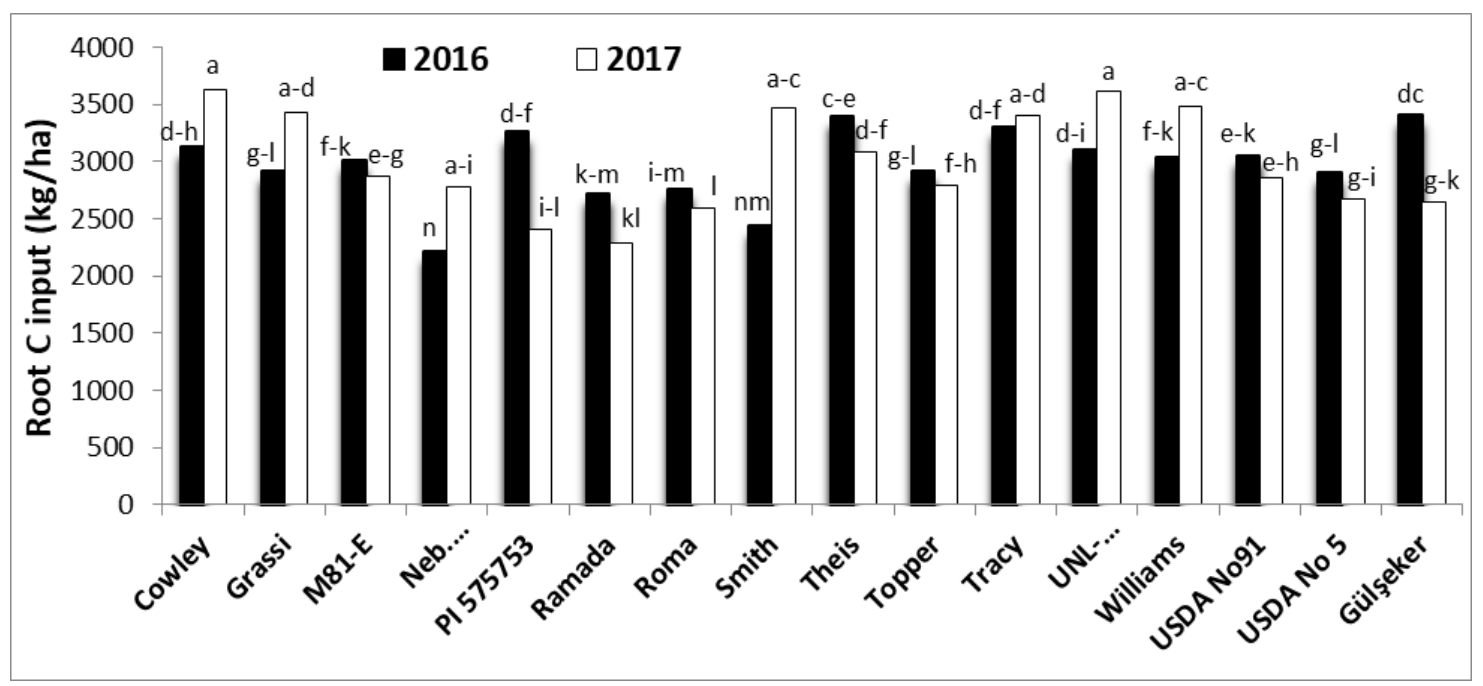

Fig 1b: Root C inputs in several sweet sorghum genotypes at a depth of 0-30 cm for Harran soil (Sanliurfa location). Data were means of three replicates. Means followed by the same letter within a column are not significantly differed at $P \geq 0.05$ based on the Tukey test. 
Table 2. Genotypes of sweet sorghum used in the study.

\begin{tabular}{lc}
\hline Genotype Name & Received organization \\
\hline Cowley & The University of Nebraska /USA \\
Grassi & The University of Nebraska/USA \\
M81-E & The University of Nebraska/USA \\
Nebraska sugarcane & The University of Nebraska /USA \\
PI 575753 & The University of Nebraska /USA \\
Ramada & The University of Nebraska /USA \\
Roma & The University of Nebraska /USA \\
Smith & The University of Nebraska /USA \\
Theis & The University of Nebraska /USA \\
Topper & The University of Nebraska /USA \\
Tracy & The University of Nebraska /USA \\
UNL-Hybrid 3 & The University of Nebraska /USA \\
Williams & The University of Nebraska /USA \\
USDA No91 & USDA (Originated from Taiwan) USA \\
USDA No 5 & USDA (Originated from South America) USA \\
Gülşeker & Uludag University. Faculty of Agriculture, Turkey. \\
\hline
\end{tabular}

Prof. Dr. İsmail Dweikat, The University of Nebraska, Lincoln, USA, USDA, U.S. Department of Agriculture)

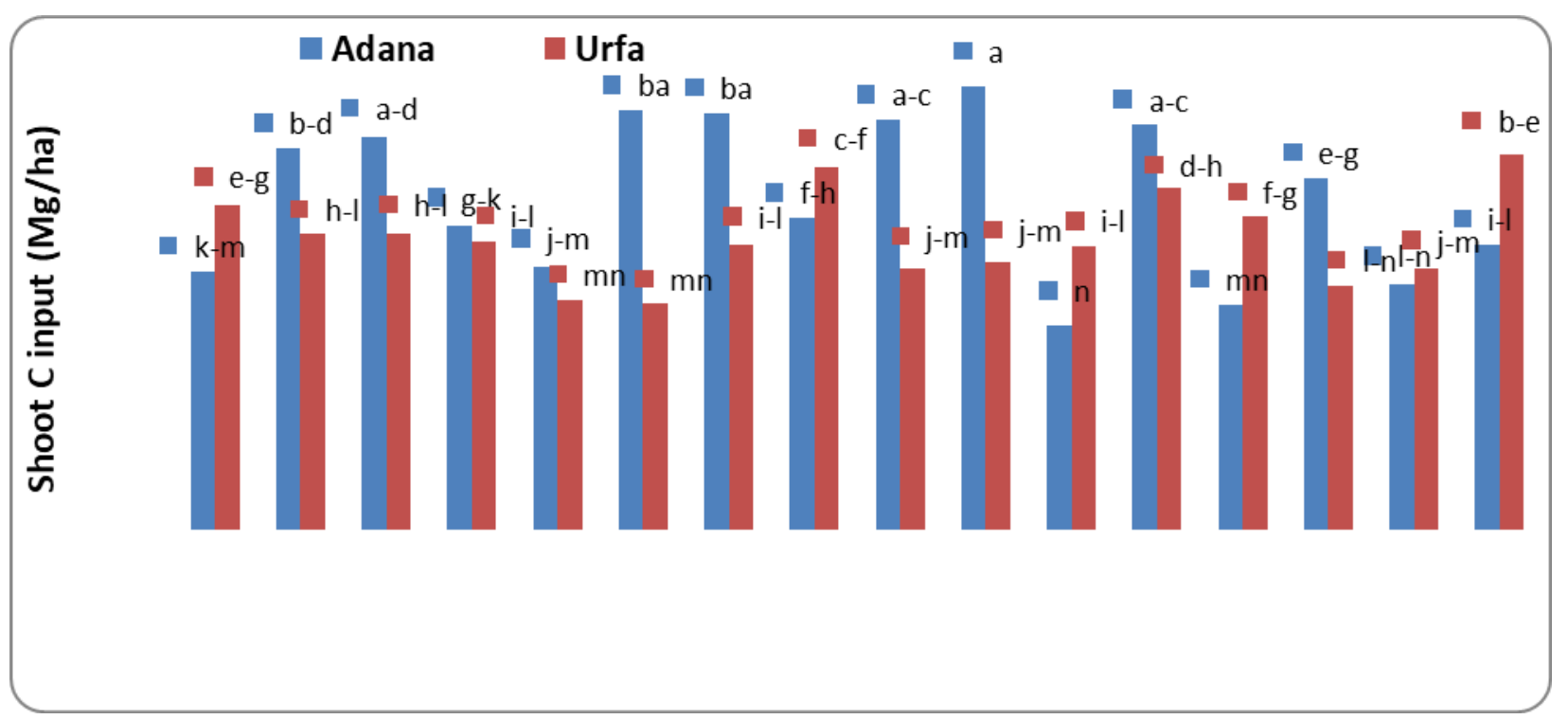

Fig 2. Shoot $C$ inputs in several sweet sorghum genotypes for Mediterranean soil (Adana location) and Harren soil (Urfa location). Data were means of three replicates. Two year data (2016 and 2017) average. Means followed by the same letter within a column are not significantly differed at $\mathrm{P} \geq 0.05$ based on the Tukey test. 
Table 3. Sweet sorghum genotypes growth response that grown in two years in two locations.

\begin{tabular}{|c|c|c|c|c|c|c|c|}
\hline \multirow[b]{2}{*}{ Treatment } & \multirow[b]{2}{*}{ Genotype } & \multicolumn{2}{|c|}{ Plant height } & \multicolumn{2}{|c|}{ Shoot dry weight } & \multicolumn{2}{|c|}{ Root dry weight } \\
\hline & & 2016 & 2017 & 2016 & 2017 & 2016 & 2017 \\
\hline & & $\mathrm{cm}$ & $\mathrm{cm}$ & $\mathrm{kg} / \mathrm{ha}$ & $\mathrm{kg} / \mathrm{ha}$ & $\mathrm{kg} / \mathrm{ha}$ & $\mathrm{kg} / \mathrm{ha}$ \\
\hline \multirow{16}{*}{ Adana } & Cowley & $338 n q$ & $367 \mathrm{hm}$ & 32381gl & 36730jp & $6395 \mathrm{dg}$ & $6173 \mathrm{ei}$ \\
\hline & Grassi & 393ef & 389ci & $34730 f k$ & $54222 b d$ & $7578 b a$ & $7513 \mathrm{ba}$ \\
\hline & M81-E & $422 d c$ & 410ae & $34825 \mathrm{fk}$ & $57143 b d$ & 5515kj & 5273jl \\
\hline & Nebraska sugarcane & $368 \mathrm{il}$ & $393 \mathrm{bh}$ & $37873 b-g$ & 43524gj & 6159dj & 5988ej \\
\hline & PI 575753 & $347 \mathrm{mp}$ & $337 m p$ & $29397 k l$ & 37651ip & 6168di & $5847 \mathrm{fk}$ \\
\hline & Ramada & 363jm & $373 \mathrm{fj}$ & 35714 ej & $59048 a c$ & $5510 \mathrm{kj}$ & 5450il \\
\hline & Roma & 337 oq & $313 p$ & $32794 \mathrm{gl}$ & $60952 \mathrm{ba}$ & 5669hk & 5291jl \\
\hline & Smith & 367il & $352 \mathrm{ko}$ & $42095 \mathrm{cb}$ & 45175eh & 6780ce & 6592ce \\
\hline & Theis & 408ed & $412 \mathrm{ad}$ & 30571jl & 57905ad & 5673hk & 5401jl \\
\hline & Topper & $377 \mathrm{fj}$ & $365 \mathrm{hm}$ & $49175 a$ & $65016 a$ & $7982 a$ & $7875 a$ \\
\hline & Tracy & $3350 \mathrm{q}$ & $372 \mathrm{fj}$ & $31778 \mathrm{hl}$ & $31270 p$ & 6190di & 6221eh \\
\hline & UNL-Hybrid 3 & $437 a c$ & $425 a$ & $48603 a$ & 59778 ba & $8118 a$ & 7337ba \\
\hline & Williams & $330 p q$ & $325 o p$ & 290481 & 31905np & 5578ik & 49381 \\
\hline & USDA No91 & $427 b c$ & 407ae & 41841bd & 52381ce & 5669hk & $5511 \mathrm{hl}$ \\
\hline & USDA No 5 & $383 \mathrm{fi}$ & 360in & $38667 b f$ & 35937lp & 5986gj & $5635 \mathrm{gl}$ \\
\hline & Gülşeker & $325 q$ & $352 \mathrm{ko}$ & $48540 a$ & $42317 \mathrm{gl}$ & 6780ce & 7164ad \\
\hline \multirow{16}{*}{ Sanliurfa } & Cowley & 35210 & 380ek & $35524 \mathrm{ej}$ & 46000eg & $6695 \mathrm{cf}$ & $7579 b a$ \\
\hline & Grassi & $446 a$ & 413ac & 30952il & 43238gk & 6077gj & $7460 \mathrm{ba}$ \\
\hline & M81-E & $379 \mathrm{fj}$ & 383dj & 36857ch & $42984 \mathrm{gl}$ & $6135 \mathrm{ej}$ & 6230eh \\
\hline & Nebraska sugarcane & $380 f j$ & 358jn & 40762be & $43016 \mathrm{gl}$ & 45121 & $5833 \mathrm{fk}$ \\
\hline & PI 575753 & $442 b a$ & 405ae & 32127hl & 31683op & $6807 d c$ & $5556 \mathrm{gl}$ \\
\hline & Ramada & $388 \mathrm{gf}$ & 380ek & $32921 \mathrm{gl}$ & $34286 \mathrm{mp}$ & 5697hk & 5119kl \\
\hline & Roma & $367 i l$ & $368 \mathrm{gl}$ & $34063 f l$ & 38889go & 5913gj & 5873ej \\
\hline & Smith & $365 j l$ & $383 c j$ & $32730 \mathrm{gl}$ & $54000 b d$ & $5142 \mathrm{kl}$ & $7540 \mathrm{ba}$ \\
\hline & Theis & 35210 & $3381 p$ & $34571 \mathrm{fl}$ & 38984gn & $7115 b c$ & $6508 d f$ \\
\hline & Topper & 370hk & $333 n p$ & $42762 b$ & $38222 \mathrm{hp}$ & $6281 \mathrm{dh}$ & 5952ej \\
\hline & Tracy & $383 \mathrm{fi}$ & $423 \mathrm{ba}$ & $29968 k l$ & 39683gm & 6729ce & $7103 b d$ \\
\hline & UNL-Hybrid 3 & $437 a c$ & 400af & $36571 \mathrm{dh}$ & $51270 \mathrm{df}$ & $6655 \mathrm{cf}$ & 7619ba \\
\hline & Williams & 365jl & 398ag & $34730 \mathrm{fk}$ & $44540 f i$ & 6134ej & $7262 a c$ \\
\hline & USDA No91 & $375 g j$ & 363in & 36413di & $36254 \mathrm{kp}$ & $6497 \mathrm{cg}$ & $6270 \mathrm{eg}$ \\
\hline & USDA No 5 & $355 \mathrm{kn}$ & $3401 p$ & $31873 \mathrm{hl}$ & 37333ip & 6185di & $5556 \mathrm{gl}$ \\
\hline & Gülşeker & $386 \mathrm{fh}$ & $427 a$ & $33778 \mathrm{gl}$ & $54508 b d$ & $6671 \mathrm{cf}$ & $6206 \mathrm{eh}$ \\
\hline
\end{tabular}

Data were means of three replicates. Means followed by the same letter within a column are not significantly differed at $P \geq 0.05$ based on the Tukey test.

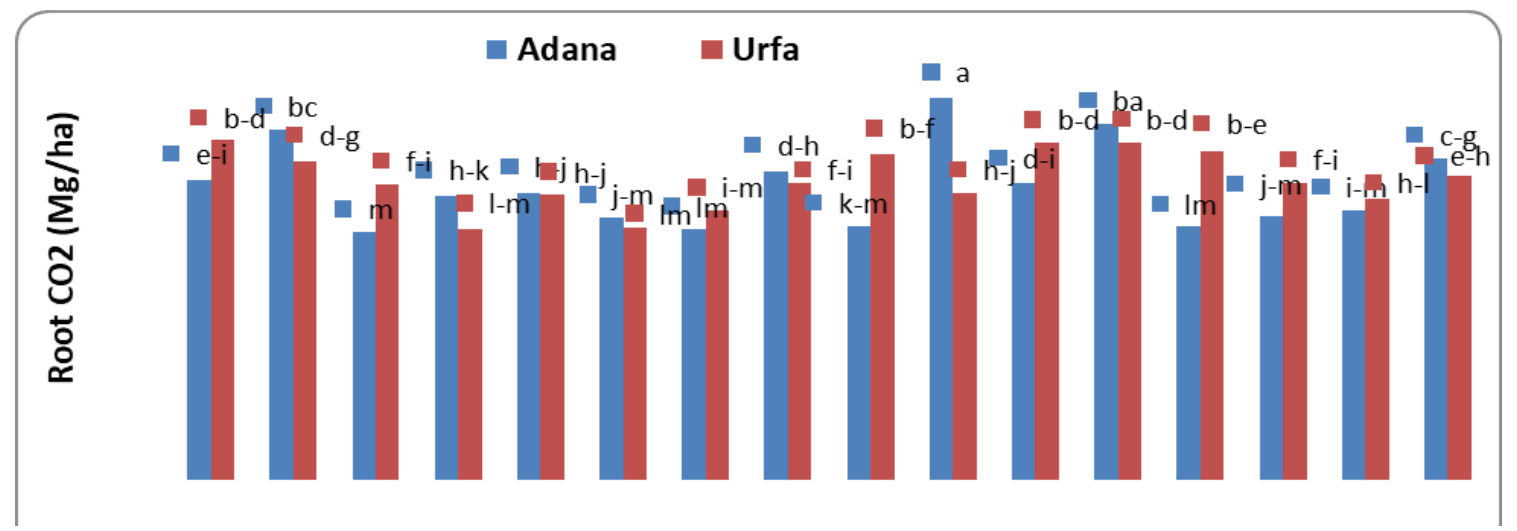

Fig 3. Root $\mathrm{CO}_{2}$ in several sweet sorghum genotypes for Mediterranean soil (Adana location) and Harren soil (Urfa location).. Data were means of three replicates. Two years (2016 and 2017) average. Means followed by the same letter within a column are not significantly differed at $\mathrm{P} \geq 0.05$ based on the Tukey test. 
Table 4. Root morphological characteristics of several sweet sorghum genotypes.

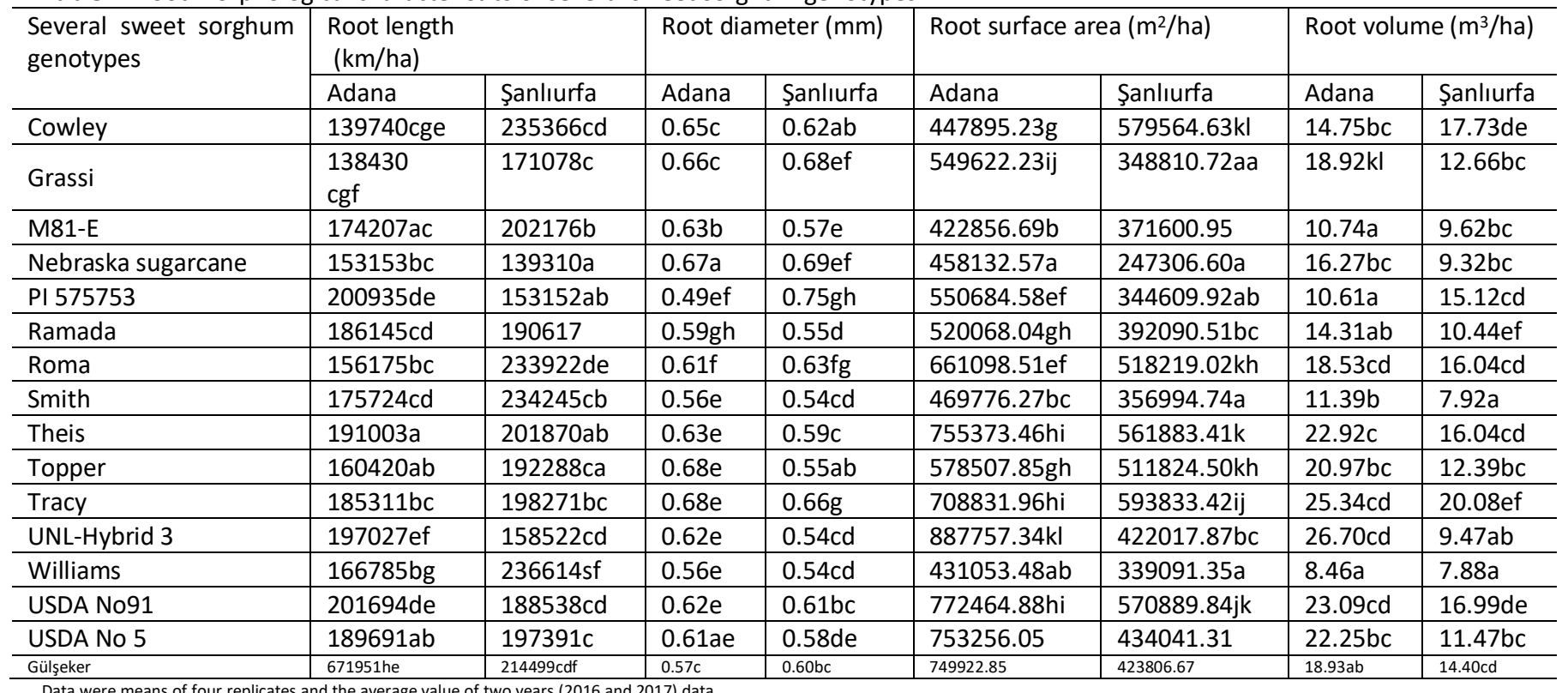

Data were means of four replicates and the average value of two years (2016 and 2017) data.

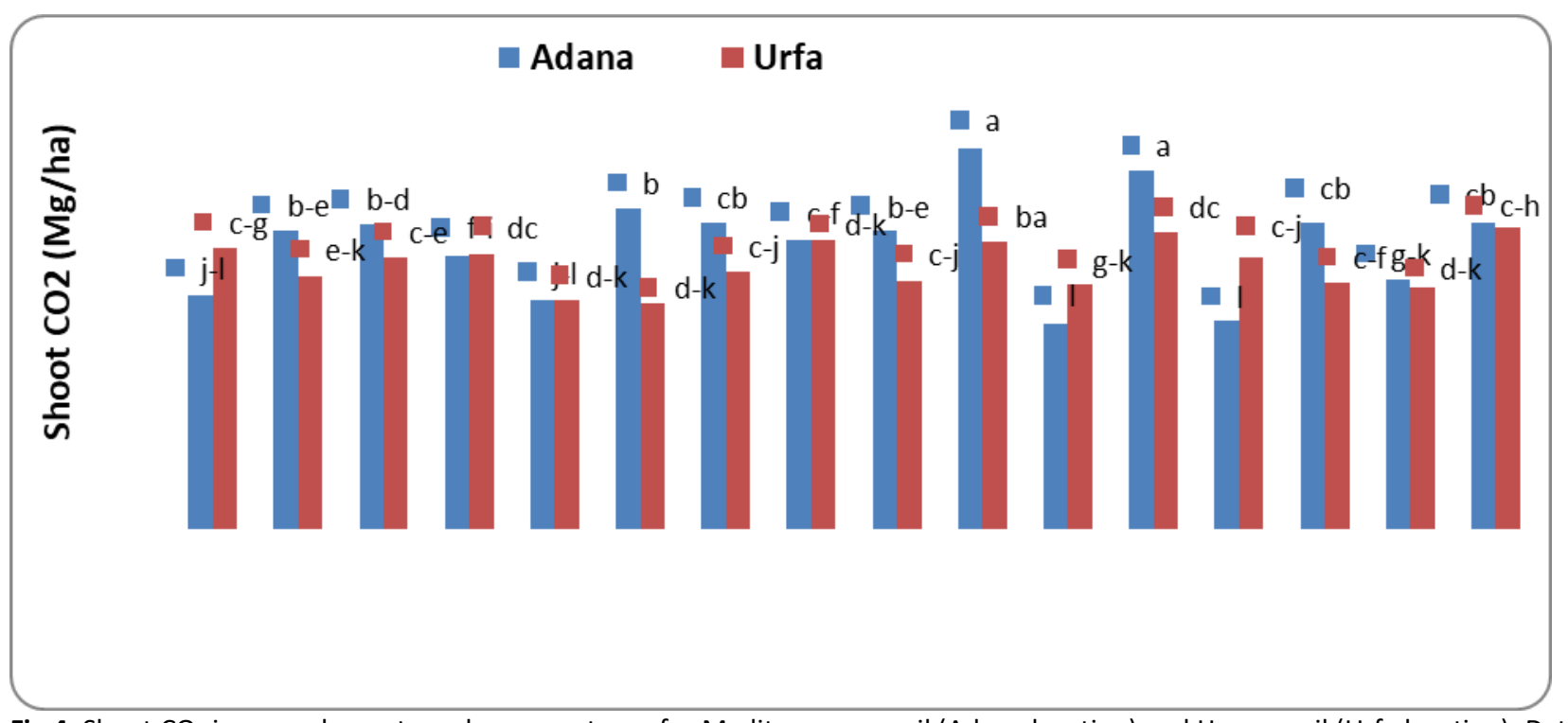

Fig 4. Shoot $\mathrm{CO}_{2}$ in several sweet sorghum genotypes for Mediterranean soil (Adana location) and Harren soil (Urfa location). Data were means of three replicates. Two years (2016 and 2017) average. Means followed by the same letter within a column are not significantly differed at $\mathrm{P} \geq 0.05$ based on the Tukey test.

Table 5. Level of significance for the main and interactive effect on root morphological characteristics and root biomass of several sweet sorghum genotypes

\begin{tabular}{llllll}
\hline Sources of variations & Root & \multicolumn{2}{l}{ Root morphological characteristics } & \\
\cline { 3 - 6 } & biomass & Root length & Root surface area & Root diameter & Root volume \\
\hline Locations & $* * *$ & n.s. & $* * *$ & n.s. & $* *$ \\
Genotypes & n.s. & $*$ & $* * *$ & $*$ & $* *$ \\
Locations $\times$ Genotypes & n.s. & n.s. & $* *$ & n.s. & $* *$ \\
\hline
\end{tabular}




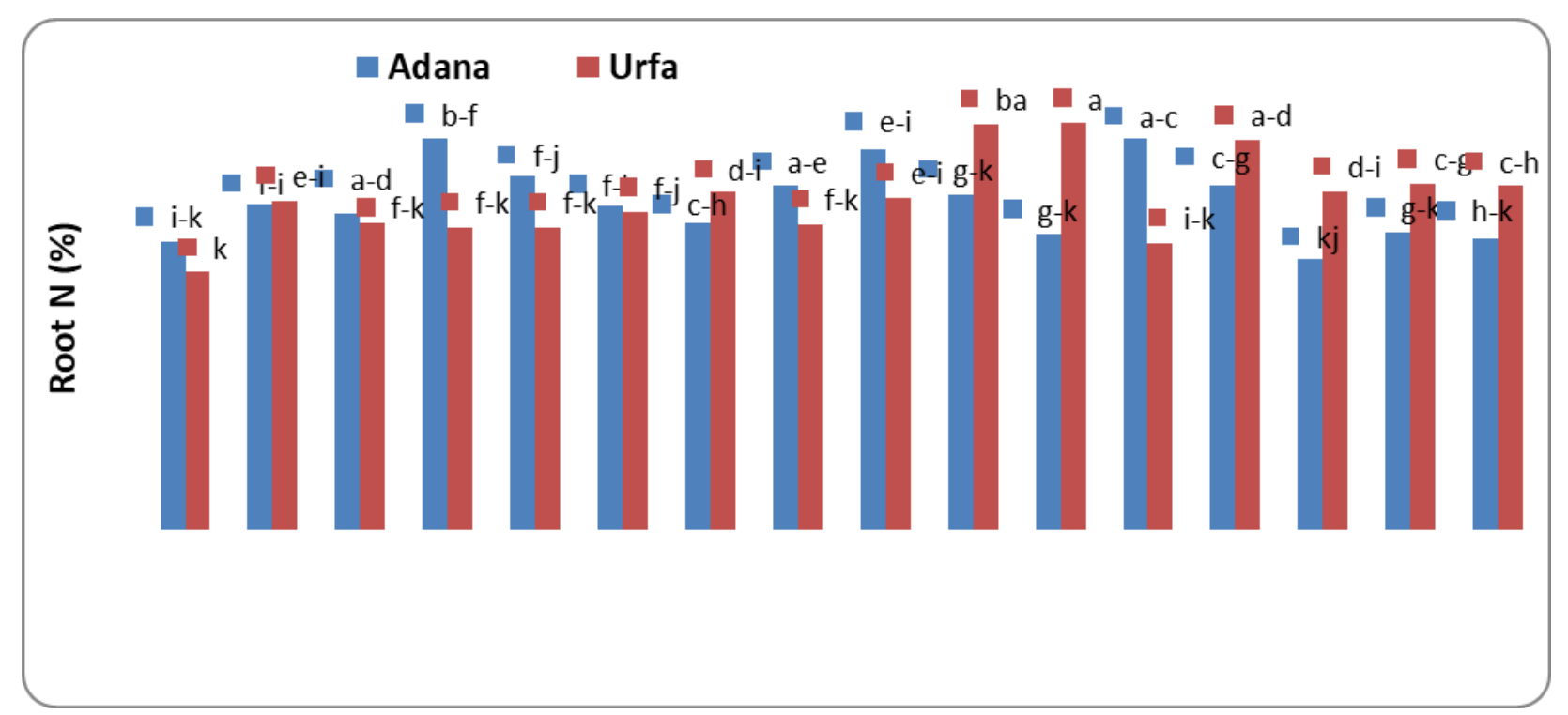

Fig 5. Root $\mathrm{N}$ in several sweet sorghum genotypes for Mediterranean soil (Adana location) and Harren soil (Urfa location). Data were means of three replicates. Two years (2016 and 2017) averaged. Means followed by the same letter within a column are not significantly differed at $\mathrm{P} \geq 0.05$ based on the Tukey test.

Table 6: Level of significance for the main and interactive effect locations and genotypes on root morphological characteristics of several sweet sorghum genotypes.

\begin{tabular}{lllll}
\hline Sources of variations & Root C inputs & Shoot C inputs & Root $\mathrm{CO}_{2}$ & Shoot $\mathrm{CO}_{2}$ \\
\hline Locations & $* * *$ & $* * *$ & $* * *$ & $* * *$ \\
Genotypes & n.s. & n.s. & n.s. & n.s. \\
Locations $\times$ Genotypes & $* *$ & n.s. & $* *$ & n.s. \\
\hline Where n.s. ${ }^{* *}$ and $* *$ represents probability of $>0.05, \leq 0.01$ and $\leq 0.001$ respectively. Values were & means of four replicates.
\end{tabular}

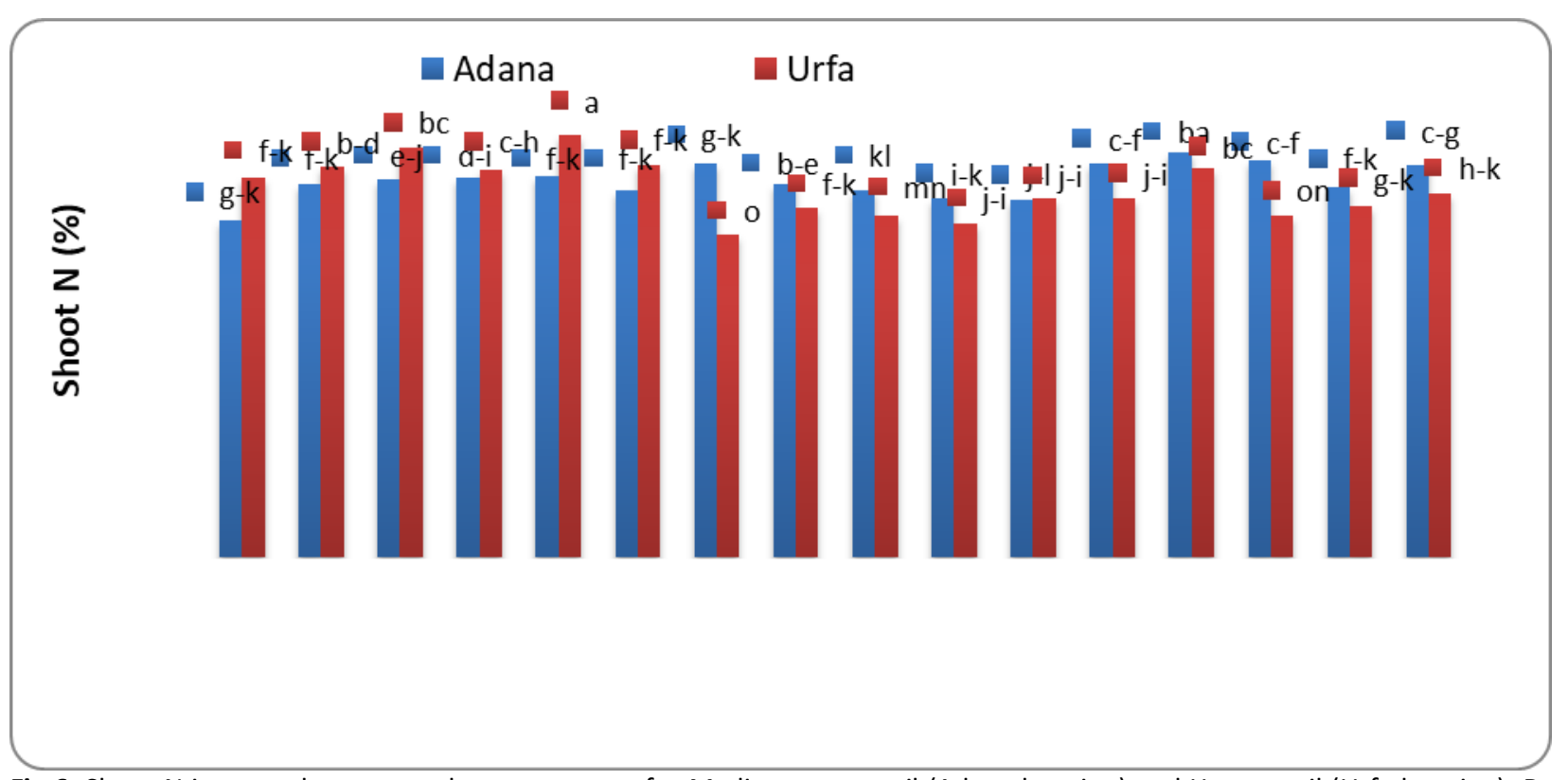

Fig 6. Shoot $\mathrm{N}$ in several sweet sorghum genotypes for Mediterranean soil (Adana location) and Harren soil (Urfa location). Data were means of three replicates. Two years $(2016$ and 2017) averaged. Means followed by the same letter within a column are not significantly differed at $\mathrm{P} \geq 0.05$ based on the Tukey test. 
Table 7. Level of significance for the main and interactive effect locations and genotypes on root $\mathrm{N}$, shoot $\mathrm{N}$, soil $\mathrm{C}$ stock as well as soil $\mathrm{N}$ stock.

\begin{tabular}{lllll}
\hline Sources of variations & Root N & Shoot N & Soil C stock & Soil N stock \\
\hline Locations & n.s. & $* * *$ & $* * *$ & $* * *$ \\
Genotypes & $*$ & n.s. & n.s. & n.s. \\
Locations $\times$ Genotypes & $* *$ & $*$ & n.s. & n.s. \\
\hline Where $n$. s. $^{* *}$ and $* * *$ represents probability of $>0.05, \leq 0.01$ and $\leq 0.001$ respectively Values were
\end{tabular}

Where n.s. ${ }^{* *}$ and $* * *$ represents probability of $>0.05, \leq 0.01$ and $\leq 0.001$ respectively. Values were means of four replicates.

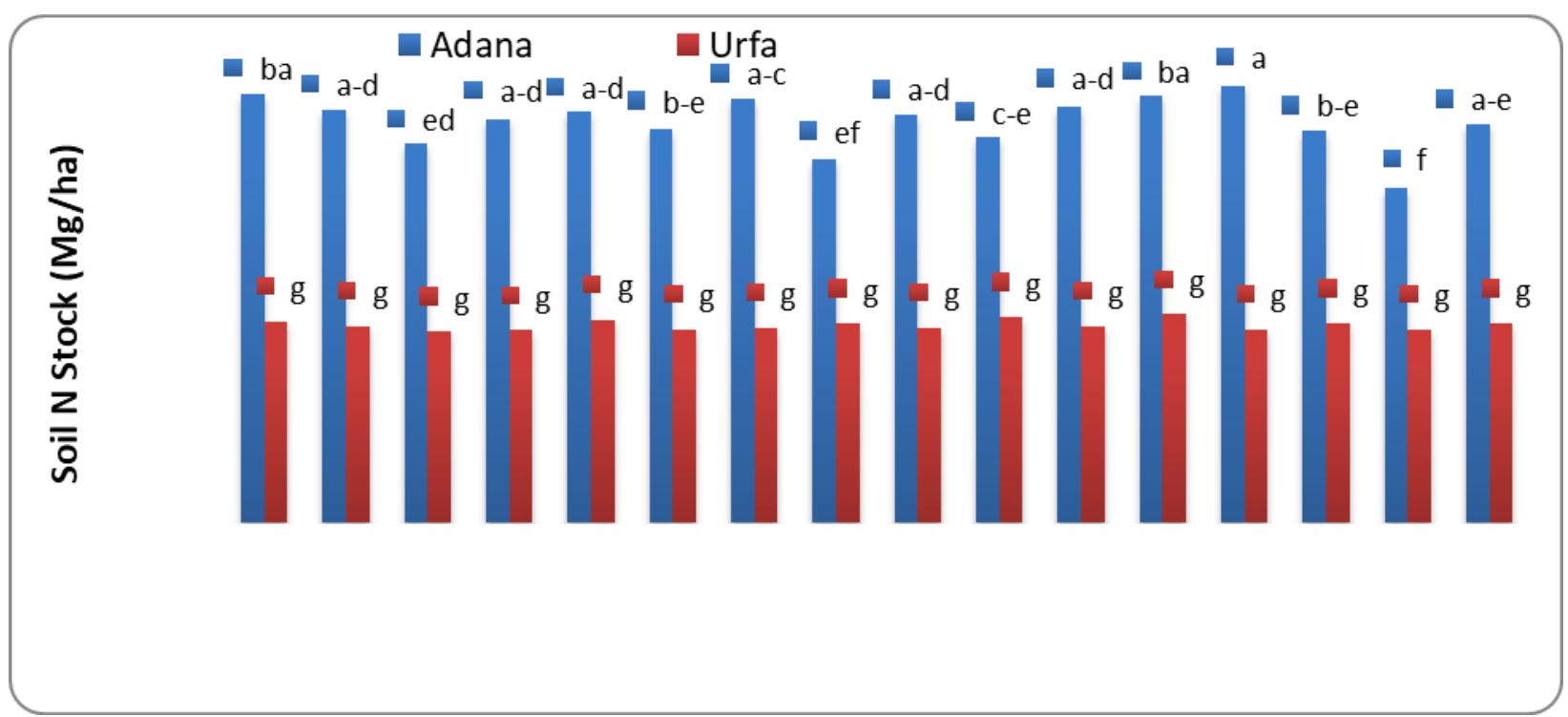

Fig 7. Soil $\mathrm{N}$ stock in several sweet sorghum genotypes for Mediterranean soil (Adana location) and Harren soil (Urfa location). Data were means of three replicates. Two years (2016 and 2017) averaged. Means followed by the same letter within a column are not significantly differed at $\mathrm{P} \geq 0.05$ based on the Tukey test.

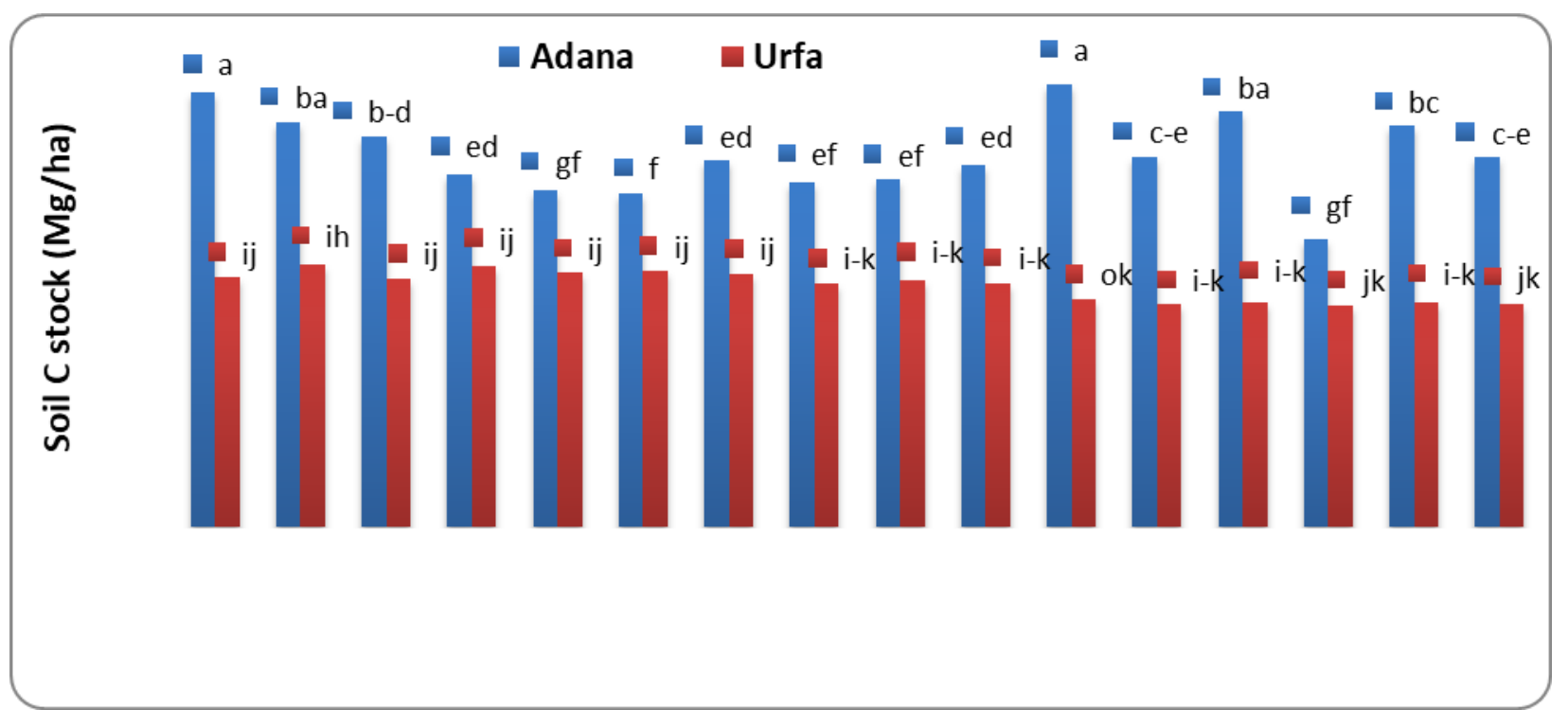

Fig 8. Soil C stock in several sweet sorghum genotypes for Mediterranean soil (Adana location) and Harren soil (Urfa location). Data were means of four replicates. Two years (2016 and 2017) averaged. Means followed by the same letter within a column are not significantly differed at $\mathrm{P} \geq 0.05$ based on the Tukey test. 


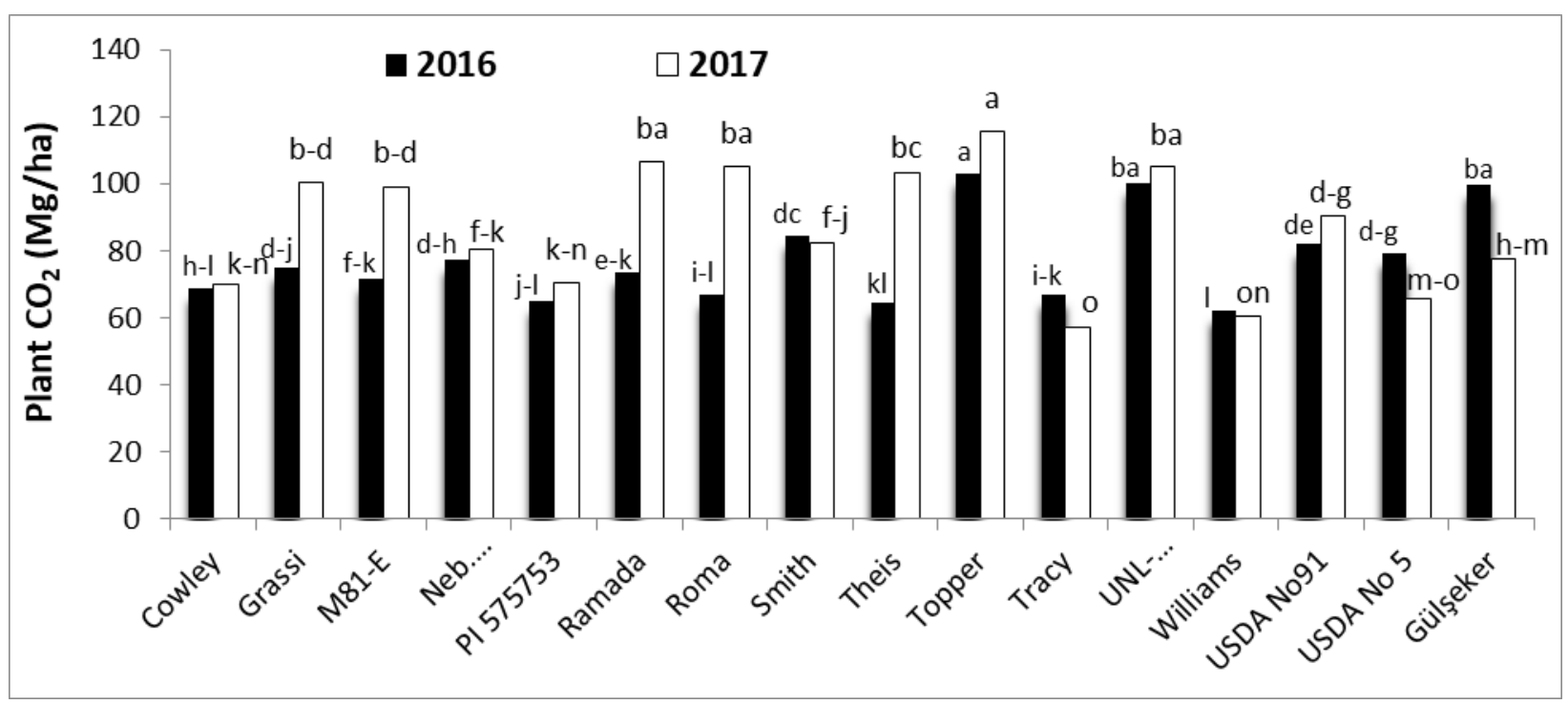

Fig 9a. Plant $\mathrm{CO}_{2}$ in several sweet sorghum genotypes at a depth of 0-30 cm for Mediterranian soil (Adana location). Data were means of three replicates. Means followed by the same letter within a column are not significantly differed at $\mathrm{P} \geq 0.05$ based on the Tukey test.

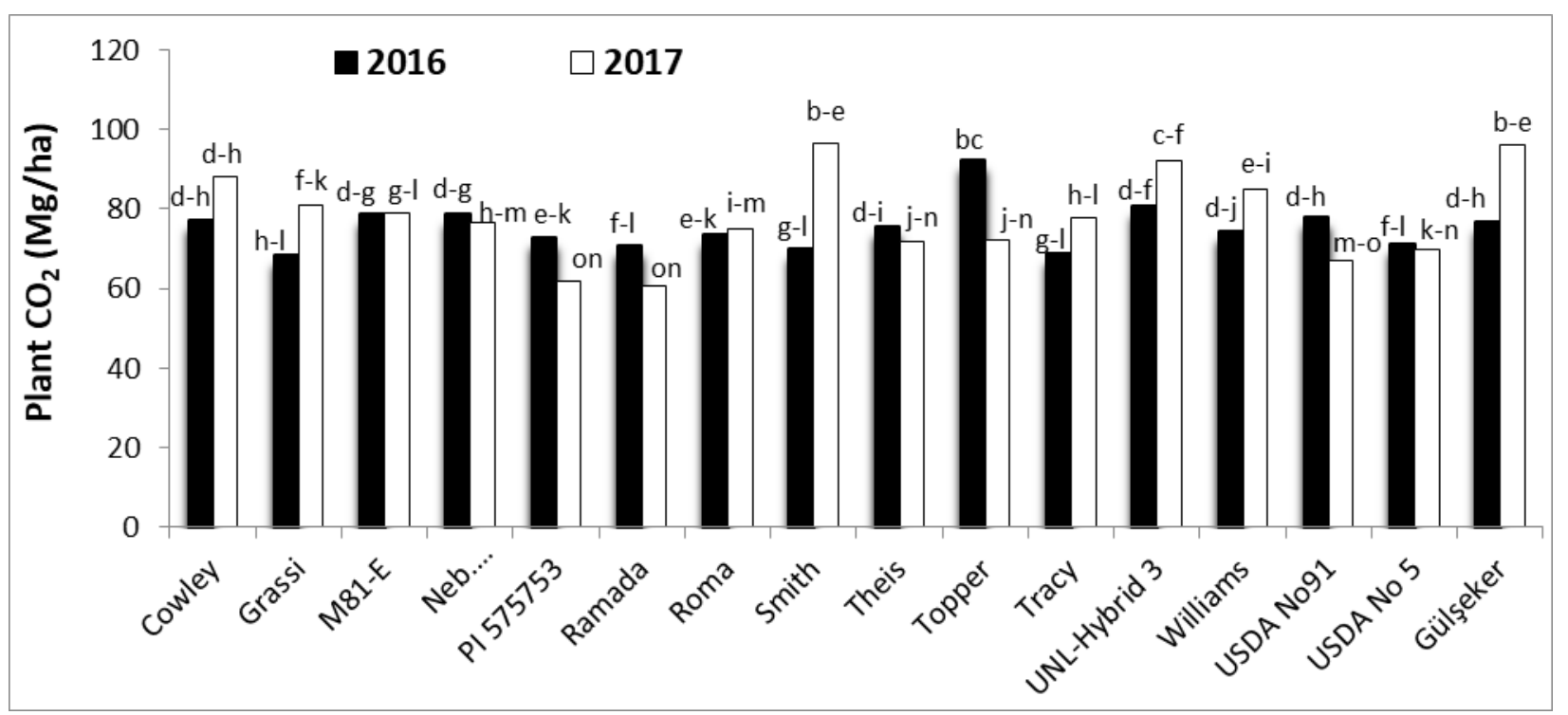

Fig 9b. Plant $\mathrm{CO}_{2}$ in several sweet sorghum genotypes at a depth of 0-30 cm for Harran soil (Sanliurfa location). Data were means of three replicates. Means followed by the same letter within a column are not significantly differed at $P \geq 0.05$ based on the Tukey test.

found $824 \mathrm{Mg} / \mathrm{ha}$ for $\mathrm{P} 1579753$ genotypes and minimum root $\mathrm{CO}_{2}$ was found $428 \mathrm{Mg} /$ ha at Şanlıurfa location.

\section{Shoot Carbon Fixation was Converted into $\mathrm{CO}_{2}$}

Shoot $\mathrm{CO}_{2}$ fixation in several sweet sorghum genotypes in Adana than Şanlıurfa location (Figure 4). Several sweet genotypes shoot $\mathrm{CO}_{2}$ differ significantly $(P \geq 0.05)$ differed between two locations. However, genotypes and locations $x$ genotypes interactions did not differ (Table 6). The maximum shoot $\mathrm{CO}_{2}$ fixation was found $12236 \mathrm{Mg} /$ ha for BATAEM-4 sweet sorghum genotypes and minimum shoot $\mathrm{CO}_{2}$ fixation was found $4584 \mathrm{Mg} / \mathrm{ha}$ for white Orn genotypes in Adana location. Similarly, maximum shoot $\mathrm{CO}_{2}$ fixation was found in Nebraska Sugarcane $7059 \mathrm{Mg} / \mathrm{ha}$ and minimum hoot $\mathrm{CO}_{2}$ fixation was found $3721 \mathrm{Mg} / \mathrm{ha}$ for Grassi sweet sorghum genotypes at Şanlıurfa locations.

Root N

Root N\% was higher in Şanlıurfa than Adana location with some exception (Figure 5). The maximum root N\% was found 1.90 for BATEM-5 and minimum root N\% was found 0.78 for P1579753 sweet sorghum genotypes at Şanlıurfa location. The 
maximum root $\mathrm{N} \%$ was 1.21 for $\mathrm{P} 1579753$ and Theis genotypes and minimum root $\mathrm{N} \%$ was 0.86 for BATAEM- genotypes at Adana locations. Root N\% differed significantly $(P \geq 0.05)$ among genotypes as well as locations $\times$ genotypes interactions (Table 7).

\section{Shoot $N$}

Shoot N\% was higher in Adana than Şanlıurfa location in several sweet sorghum genotypes (Figure 6). The maximum shoot N\% was 1.93 in White Orn and minimum was 1.28 in Theis sweet sorghum genotypes at Adana location. Likewise, the maximum shoot N\% was 1.29 for Tracy and minimum was 0.82 for Cowley genotypes. Shoot $\mathrm{N}$ differed significantly $(P \geq$ $0.05)$ between locations as well as location $\times$ genotypes interactions (Table 7).

\section{Soil C stock}

Soil $\mathrm{C}$ stock by several sweet sorghum genotypes was double in Adana than Şanlıurfa location (Figure 7). The highest soil C stock was in White Orn $93 \mathrm{Mg} / \mathrm{ha}$ and lowest soil C stock was BATAEM-4 60.26 at Adana location. The soil C stock did not differ among sweet sorghum genotypes at Şanlıurfa location and it ranges from 47 to $55 \mathrm{Mg} / \mathrm{ha}$.

\section{Soil $N$ stock}

Soil N stock was 2-3 times higher in Adana than Şanlıurfa locations (Figure 8). Soil $\mathrm{N}$ stock varies from 3 to $4 \mathrm{Mg} / \mathrm{ha}$ at Adana locations. Likewise, soil N stock varies from 1.83 to 2.03 $\mathrm{Mg} / \mathrm{ha}$ at Şanlıurfa locations. However, soil $\mathrm{N}$ stock did not differ among genotypes as well as locations $\times$ genotypes interactions at both Adana and Şanlıurfa locations (Table 7).

\section{Plant biomass $\mathrm{CO}_{2}$}

On average, plant biomass $\mathrm{CO}_{2}$ was higher in 2017 than 2016 in Adana location (Figure 9a). The plant biomass $\mathrm{CO}_{2}$ varied 62103 and 57-115 Mg/ha in the year 2016 and 2017, respectively at Adana location. In general, plant biomass $\mathrm{CO}_{2}$ was higher in 2017 than 2016 in Sanliurfa location (Figure 9b). The plant biomass $\mathrm{CO}_{2}$ varied $69-93$ and 62-97 Mg/ha in the year 2016 and 2017, respectively at Sanliurfa location.

\section{Discussion}

\section{Genotypic responses to root morphological characteristics}

Several sweet sorghum genotypes responded differently irrespective to root morphological characteristics. Root volume was lowest in UNL-hybrid-5 sweet sorghum genotypes for both sites (Table 4). Root surface area and root volume among genotypes, location as well as location $\times$ genotypes interactions significantly $(p \leq 0.05)$ differed at depth of $0-30 \mathrm{~cm}$ (Table 5). Our study showed that root length $(0-30 \mathrm{~cm})$ of several sweet sorghum genotypes varies from 139310 to
$235366 \mathrm{~km} / \mathrm{ha}$ (Table 4). Likewise, a study found that root length in 0-30 cm soil layer for sweet sorghum species varies from 31 to $46 \mathrm{~m} / \mathrm{g}$ (Thivierge et. al., 2014). Furthermore, root diameter influences the decomposition and turnover of roots, where smaller fine roots ( $<2 \mathrm{~mm}$ diameter) have a faster decomposition and turnover (Pacaldo et. al., 2014). The ratio of root length to root dry mass is a widely used indicator is the ability of crops to compete for below ground nutrients (Zegada et. al., 2012). There is no information about sweet sorghum root morphological characteristics, which is required to estimate the contribution of soil $\mathrm{C}$ and $\mathrm{N}$ inputs. However, some sweet sorghum genotypes had coarse root diameter in both sites that may contribute to soil $C$ input into soil. Likewise, several studies have suggested that sweet sorghum $C$ inputs into the soil could be explained by their root system architecture (Ceotto et. al., 2013). Our finding indicates scope for enhancing soil $C$ sequestration by cultivating collected several USA sweet sorghum genotypes. Similarly, the longer and finer root system of sweet sorghum genotypes likely contributes to higher $\mathrm{N}$ uptake efficiency. Thus, not only higher $\mathrm{N}$ uptake efficiency but also morphological characteristics of roots should be taken into account when assessing $C$ input from roots.

\section{C and $N$ stocks in root and soil}

Shoot $\mathrm{N}$ concentration was higher than root $\mathrm{N}$ concentration (Figure 5 and Figure 6). Our study found that several sweet sorghum genotypes on soil $\mathrm{N}$ stock varies 1.83 to $4.16 \mathrm{Mg}$ $\mathrm{N} /$ ha. Likewise, other study found that sorghum plant $\mathrm{N}$ stock in soil was $2.47 \mathrm{Mg} \mathrm{N} /$ ha (Das et al., 2016). Similarly, shoot C input was ten times higher than root $C$ input (Figure 1 and Figure 2). Likewise, Shoot $\mathrm{CO}_{2}$ fixation was 8 to 10 times higher than root $\mathrm{CO}_{2}$ fixation (Figure 3 and Figure 4). Several sweet sorghum genotypes sequester too much $\mathrm{C}$ in soil as compared to $\mathrm{N}$ stock in soil. Besides their specific function in $\mathrm{N}$ uptake, very fine roots could also play a key role in soil $\mathrm{C}$ sequestration. This study confirmed that several sweet sorghum genotypes have the ability to $C$ sink in soil. The amount of $C$ stock in soil by several sweet sorghum genotypes depends on land-use change and management practices of several sweet sorghum cultivation (Tolbert et al., 2002).

Sweet sorghum genotypes have high shoot $\mathrm{N}$ than root $\mathrm{N}$ (Figure 5 and Figure 6). Shoot $\mathrm{N}$ varies from 0.82 to $1.88 \%$ and root $\mathrm{N}$ varies from 0.78 to $1.90 \%$. This difference could be related to the stronger ability of sweet sorghum roots to secrete nitrification inhibitors that likely helped in competing for soil $\mathrm{N}$ and may have compensate lower root $\mathrm{N}$ than shoot $\mathrm{N}$ (Tesfamariam et al., 2014).

\section{Root and shoot $\mathrm{C}$ input}

Besides their role in nutrient uptake, roots constitute a major source of C for soil (Rasse et al., 2005). Root biomass i.e root volumes were high in several sweet sorghum genotypes in our study. Root volume varies from 7.92 to $26.70 \mathrm{~m}^{3} / \mathrm{ha}$ in several sweet sorghum genotypes at both sites. Other study also 
opined that root biomass might be a good indicator of crop C input to soil (Monti \& Zatta, 2009).

Root diameter of several sweet sorghum genotypes were low and did not differ location and location $\times$ genotype interaction (Table 4 and Table 5). This minimum root diameter may cause less $C$ input in several sweet sorghum genotypes. A study speculated that roots become more numerous, longer, thicker, and faster growing in crops exposed to high $\mathrm{CO}_{2}$ with increased root length in many plant species. Branching and extension of roots under elevated $\mathrm{CO}_{2}$ may lead to altered root architecture and ability of roots to acquire water and nutrients from the soil profile with exploration of the soil volume. Root turnover is important to the global $\mathrm{C}$ budget as well as to nutrient cycling in ecosystems and individual plants. Agricultural management practices have a greater impact on root growth than rising atmospheric $\mathrm{CO}_{2}$ since management practices influence soil physical, chemical, and biological properties of soil, consequently affects root growth dynamics in the belowground (Madhu \& Hatfield, 2013).

Our results indicate that even though several sweet sorghum genotypes allocated less $C$ into their root system than shoot (Figure 1 and Figure 2), they produce larger root volume (Table 4), which likely increased their competitiveness for nutrients. Likewise, a study speculated that smaller allocation of $\mathrm{C}$ to roots along with a high root length for greater investment of $C$ to the shoot (Bonifas \& Lindquist, 2009). This could explain the high $C$ in shoot of several sweet sorghum genotypes in the present study.

\section{Materials and methods}

\section{Experimental locations}

Field experiments were located at the Eastern Mediterranean Agricultural Research Institute (Adana, 36 $51^{\circ} 35^{\prime \prime} \mathrm{K}$ and $35^{\circ}$ $20^{\prime} 43^{\prime \prime}$ D) and GAP Agricultural Research Institute in Turkey (Şanlıurfa, $36^{\circ} 42^{\prime} \mathrm{K}, 38^{\circ} 58^{\prime} \mathrm{D}$ ).

\section{Experimental design}

The experimental designs were 2 locations $\times 16$ genotypes $\times 2$ seasons. The sixteen sweet sorghum genotypes were evaluated as randomized complete block design with four replications. The locations were Adana and Şanlıurfa. The sweet sorghum genotypes growing season in Turkey is June to September. The experiments were conducted in the year of 2016 and 2017. The sources sweet sorghum genotypes used in this study was shown in Table 1. Most of the genotypes used in this study were collected from the Nebraska University, USA.

\section{Soil and climatic conditions of experimental sites}

in Table 2. Soil samples were taken from 0-30 cm depth from the experimental sites in the Adana location known as Mediterranean soils. Some of the best-known examples of Mediterranean soils are the famous "terra rossa" or the Rhodic and Chromic Luvisols the Rhodoxeralfs of Soil Taxonomy (Soil
Survey Staff, 2006). The Mediterranean soil initial physiochemical properties were $\mathrm{pH}$ value 7.72 , average lime content $20 \%$, organic matter $2 \%$, sand $27.8 \%$, clay $31.2 \%$ and silt was $41 \%$. The average temperature for the June-September period in Adana was 27 드. the average sunshine duration was 10 hours, the highest average temperature was $33.3 \stackrel{\circ}{\circ}$ and the average relative humidity was $66 \%$ (General Directorate of Meteorology Station, 2014).

The experiment under the conditions of Şanlıurfa was conducted in the Harran soil Series, which was a wide, spread area in the region and was located entirely in the research station. These series soils were alluvial parent material, flat and nearly flat inclined deep-profiled soils (Sakin et. al., 2010). Typical red profiles were clayey textured and the entire profile was very calcareous (Table 1 ). The $A, B, C$ horizon soils, $\mathrm{pH}$ was between 7.3-7.8 and organic matter content was low, cation exchange capacity (CEC) was high. The average temperature for the June-September period was 29.5 으, the mean sunshine duration was 11.48 hours, the highest temperature was $44.4 \stackrel{\circ}{\circ}$ and the average relative humidity was around $36.5 \%$ (General Directorate of Meteorology Station, 2014).

\section{Experimental management}

The experiments were conducted in summer seasons (June to September) of Turkey in the year of 2016 and 2017. The plot sizes of each experiment were $5 \times 5 \mathrm{~m}^{2}$. Each plot contained 4 lines. The line to line distance was $70 \mathrm{~cm}$. The plant to plant distance was $15 \mathrm{~cm}$. Initial seeding rates of both two year experiments were 70,000 seeds ha-1. Each plot was thinned to 10 plants at 10 days after sowing (DAS). Triple super phosphate (TSP) was used as a phosphorus fertilizer source. A $50 \mathrm{P}_{2} \mathrm{O}_{5} \mathrm{~kg} \mathrm{ha}^{-1}$ was applied as a basal dose. Urea was applied as a nitrogen $(\mathrm{N})$ fertilizer source. $\mathrm{A} 100 \mathrm{~kg} \mathrm{~N} \mathrm{ha}^{-1}$ was applied as split dose. A first and second split dose of $\mathrm{N}$ was applied at 15 and 45 DAS. The plant was harvested at 89 DAS in both years.

\section{Root sample collection procedure}

Root samples were collected according to monolith root sampling techniques (Riedell \& Osborne, 2017). Monolith sampling was used to remove a soil block $(30 \mathrm{~cm}$ long by $10 \mathrm{~cm}$ wide by $30 \mathrm{~cm}$ deep) in which root length was measured after grid sampling. Soil-root monoliths were taken on the same dates as roots were dug using standard techniques. Roots were separated from soil manually and washed by tap water initially.

\section{Soil analysis}

Soil $\mathrm{pH}$ was determined by saturation using a ratio of $1: 2.5$ soil to water by $\mathrm{pH}$ meter. Electrical conductivity $(\mathrm{EC})$ were obtained in triplicate using a ratio 1:2.5 soil to water with an Orion model $115 \mathrm{~A}$ plus conductivity meter bridge (Schlichting \& Blume, 1966). The lime content of the soil was measured by Scheibler calcimetres and the results were calculated as \% 
$\mathrm{CaCO}_{3}$ (Carter, 1993). Organic Carbon was determined according to Walkley-Black method and results were calculated as \% (Nelson \& Sommers, 1982). Soil structure, the texture of the soil was determined according to (Bouyoucos, 1962).

\section{Plant and root analysis}

Sweet Sorghum was harvested at dough stage (89 days after planting). Root samples was taken $(30 \mathrm{~cm}$ long, $15 \mathrm{~cm}$ wide, and $30 \mathrm{~cm}$ deep) from soil monolith. The monolith soil sampler (Buman, Schumacher, \& Riedell, 1994), modified from the design of (Walker \& Coventry, 1976). Roots were separated from the soil manually and were washed with distilled water and oven-dried at $65^{\circ} \mathrm{C}$ for $48 \mathrm{~h}$, ground top truss through 0.5 $\mathrm{mm}$ sieve and stored prior to total nitrogen and carbon analysis. Plant and root samples collected for estimation of dry matter accumulation at 89 days after planting, total carbon (TC) and nitrogen (N) content of the plant and root samples determined by combustion using a Thermo Fisher Scientific FLASH 2000 Series CN Elemental Analyzer (Thermo Fisher Scientific, Waltham, USA).

\section{Root biomass and trait measurements}

Root samples were taken within $(0-30 \mathrm{~cm})$ soil depth and washed from soil with water, collecting all root material retained on a $250 \mu \mathrm{m}$ sieve. Samples were first passed through a $2 \mathrm{~mm}$ sieve with water to loosen the soil particles ensuring all water was collected. Root material was dried in a fan forced oven at $65^{\circ} \mathrm{C}$ for at least $48 \mathrm{~h}$ until constant weight. Root dry weights were converted to an equivalent mass per hectare of soil surface $\left(\mathrm{kg} \mathrm{ha}^{-1}\right)$ using the cross sectional surface area of the soil core. Carbon accumulation $\left(\mathrm{kg} \mathrm{ha}^{-1}\right)$ in aboveground biomass and roots was determined by multiplying dry matter weight by total $\mathrm{C}$ concentration. Annual $\mathrm{C}$ inputs from the rooting systems of sweet sorghum were estimated to determine how it may compensate for the removal of aboveground biomass. For convert of aboveground and belowground carbon to carbon dioxide calculator: One ton of carbon equals $44 / 12=11 / 3=3.67$ tons of $\mathrm{CO}_{2}$.

\section{Root morphological characteristics measurement}

The roots were separated from the shoots. The separated roots were washed 3-4 times with deionized water. Then, the whole root system was scanned by a root-system scanner. Root morphological characteristics was measured using the software WinRHIZO image analysis system (WIN MAC, Regent Instruments Inc., Quebec, Canada, http://www.regentinstruments.com/) (Arsenault et. al., 1995).

\section{Statistical analysis}

Results were analyzed by two-way analysis of variance (ANOVA) using Genstat $12^{\text {th }}$ edition for Windows (Lawes Agricultural Trust, UK). In order to investigate the effect of mycorrhizae on shoot dry weight, root dry weight, root colonization, mycorrhizal dependency, $\mathrm{C}$ and $\mathrm{N}$ dynamics data were analyzed using the Statistical Analysis System (SAS 9.1.3). All the statistical testing was performed based on $P \leq 0.05$ as the critical level for the significance of Turkey.

\section{Conclusion}

This study showed wide varying greater sweet sorghum genotype root biomass and greater root morphological characteristics in different ecological zones of Turkey. Root turnover and carbon input rate was dependent upon sweet sorghum genotype and location (4109 kg/ ha C in Adana location by Wray genotype). Several sweet sorghum genotypes offer to increase soil $\mathrm{C}$ under different climatic conditions of Turkey through increased root mass inputs and rooting depth. Findings also indicated that several sweet sorghum cultivation enhances $C$ stock in shoot, root and soils. These results indicate for enhancing soil carbon sequestration by Sweet Sorghum. Thus sweet sorghum has the capacity to sequester $C$ in soil. This study supports the establishment of annual sweet sorghum genotypes cultivation to enhance $\mathrm{C}$ and $\mathrm{N}$ stock in soil. However, there is a need for long term studies to establish soil $\mathrm{C}$ balance under different climatic condition.

\section{Acknowledgement}

This work was supported by THE SCIENTIFIC AND TECHNOLOGICAL RESEARCH COUNCIL OF TURKEY (TÜBITAK 1140945 project). Professor Toufiq lqbal is also thankful to TÜBITAK for providing him financial support for the Visiting Professorship.

\section{Reference}

Almodares A, Sepahi A, Shirvani M (1997) Sweet sorghum cultural practices in Iran. Paper presented at the Proceedings of the First International Sweet Sorghum Conference.

Almodares A, Taheri R, Chung M, Fathi M (2008) The effect of nitrogen and potassium fertilizers on growth parameters and carbohydrate contents of sweet sorghum cultivars. J Environ Biol. 29(6): 849-852.

Arsenault JL, Poulcur S, Messier C, Guay R (1995) WinRHIZO'm A root-measuring system with a unique overlap correction method. Horticulture Sci. 30, 906.

Batjes NH (1996) Total carbon and nitrogen in the soils of the world. Europ J Soil Sci. 47(2): 151-163.

Bernardes DP, Tremblay A, Gaëtan F, Bélanger G, Annie B, Philippe $S$, Vanasse A (2015) Sugar yield of sweet pearl millet and sweet sorghum as influenced by harvest dates and delays between biomass chopping and pressing. Bioenergy Res. 8(1), 100-108.

Bonifas KD, Lindquist JL (2009) Effects of nitrogen supply on the root morphology of corn and velvetleaf. J Plant Nutr. 32(8): 1371-1382.

Bouyoucos GJ (1962) Hydrometer method improved for making particle size analyses of soils. Agronomy journal, 54(5), 464-465.

Buman, RA, Schumacher, TE, \& Riedell, WE. (1994). A modified soil monolith technique for characterizing root systems. Crop Sci. 34(1): 296-299. 
Carter MR (1993) Soil sampling and methods of analysis: CRC Press.

Ceotto E, Di Candilo M, Castelli F, Badeck F-W, Rizza F, Soave C, Volta A, Villani G, Marletto V (2013) Comparing solar radiation interception and use efficiency for the energy crops giant reed (Arundo donax L.) and sweet sorghum (Sorghum bicolor L. Moench). Field Crops Res. 149: 159-166.

Costa C, Dwyer L, Zhou X, Dutilleul P, Hamel C, Reid LM, Smith DL (2002) Root morphology of contrasting maize genotypes. Agronomy J. 94(1): 96-101.

Das A, Lal R, Somireddy U, Bonin C, Verma S, Rimal BK (2016) Changes in soil quality and carbon storage under biofuel crops in central Ohio. Soil Res. 54(4), 371-382.

Dowdy RH, Smucker AJM, Dolan MS, Ferguson JC (1998) Automated image analyses for separating plant roots from soil debris elutrated from soil cores. Plant Soil. 200(1), 91-94.

Ibrahim AMA, Ortas I, Yucel C, Oktem A, Yucel D, Iqbal MT (2018) Dry weight and nutrient uptake of twenty one sweet sorghum genotypes grown in two separate locations of Turkey. Aust J Crop Sci. 12(07):1191-1199.

Quéré LC, Andres RJ, Boden T, Conway TH, Richard A, House JI, . . . Ahlström A (2012) The global carbon budget 1959-2011. Earth System Science Data Discussions. 5(2):1107-1157.

Madhu M, Hatfield JL (2013. Dynamics of plant root growth under increased atmospheric carbon dioxide. Agronomy J. 105(3):657669.

Mamoun M, Salma A (2010) Effect of nitrogen fertilization and time of harvest on chemical composition of sweet sorghum. M.Sc thesis. UOFK.

McNally SR, Laughlin DC, Rutledge S, Dodd MB, Six J, Schipper LA (2015) Root carbon inputs under moderately diverse sward and conventional ryegrass-clover pasture: implications for soil carbon sequestration. Plant Soil. 392:(1-2), 289-299.

Monti A, Zatta A (2009) Root distribution and soil moisture retrieval in perennial and annual energy crops in Northern Italy. Agriculture, Ecosystems Environment. 132(3):252-259.

Nelson DW, Sommers LE (1982) Total carbon, organic carbon, and organic matter. Methods of soil analysis. Part 2. Chemical and microbiological properties (methodsofsoilan2): 539-579.

Nickel SE, Crookston RK, Russelle MP (1995) Root growth and distribution are affected by corn-soybean cropping sequence. Agronomy J. 87(5), 895-902.

Soil Survey Staff (2006) Keys to Soil Taxonomy, 10th ed. USDANatural Resources Conservation Service, Washington, DC.

Pacaldo RS, Volk TA, Briggs RD (2014) Carbon sequestration in fine roots and foliage biomass offsets soil $\mathrm{CO} 2$ effluxes along a 19year chronosequence of shrub willow (Salix $x$ dasyclados) biomass crops. BioEnergy Research. 7(3), 769-776.

Powlson DS, Whitmore AP, Goulding KWT (2011) Soil carbon sequestration to mitigate climate change: a critical re-examination to identify the true and the false. European Journal of Soil Science. 62(1): 42-55.

Rasse DP, Rumpel C, Dignac M-F (2005). Is soil carbon mostly root carbon? Mechanisms for a specific stabilisation. Plant and soil. 269(1-2):341-356.

Riedell WE, Osborne SL (2017) Monolith root sampling elucidates western corn rootworm larval feeding injury in maize. Crop Science. 57:(6), 3170-3178.

Sage RF (2004) The evolution of C4 photosynthesis. New phytologist. 161(2):341-370.

Schlichting E, Blume H-P (1966) Bodenkundliches Praktikum; eine Einfuhrung in pedologisches Arbeiten fur Okologen, insbesondere Land-und Forstwirte, und fur Geowissenschaftler.

Schulp CJE, Nabuurs G-J, Verburg PH (2008) Future carbon sequestration in Europe-effects of land use change. Agriculture, Ecosystems Environment. 127(3): 251-264.

Sakin E, Deliboran A, Sakin ED, Tutar E (2010) Carbon stocks in harran plain soils, sanliurfa, Turkey Not Bot Hort Agrobot Cluj. 38 (3): 151-156

Tesfamariam T, Yoshinaga H, Deshpande SP, Rao PS, Sahrawat KL, Ando Y, Nakahara K, Hash CT, Subbarao GV (2014) Biological nitrification inhibition in sorghum: the role of sorgoleone production. Plant Soil. 379(1-2):325-335.

Thivierge M-N, Angers DA, Chantigny MH, Seguin P, Vanasse A (2014) Root traits and annual carbon inputs in field-grown sweet pearl millet, sweet sorghum, and grain corn. Le millet perlé sucré et le sorgho sucré comme cultures énergétiques en conditions québécoises: Potentiel de production, utilisation de l'azote, morphologie des, 103.

Thivierge M-N, Angers DA, Chantigny MH, Seguin P, Vanasse A (2016) Root traits and carbon input in field-grown sweet pearl millet, sweet sorghum, and grain corn. Agronomy J. 108(1): 459471.

Tolbert VR, Todd DE, Mann LK, Jawdy CM, Mays DA, Malik R, Bandaranayaked W, Houston A, Tyler D, Pettry DE (2002) Changes in soil quality and below-ground carbon storage with conversion of traditional agricultural crop lands to bioenergy crop production. Environmental Pollution, 116:S97-S106.

Walker PH, Coventry RJ (1976) Soil profile development in some alluvial deposits of eastern New South Wales. Soil Research. 14(3):305-317.

Wu X, Staggenborg S, Propheter JL, Rooney WL, Yu J, Wang D (2010) Features of sweet sorghum juice and their performance in ethanol fermentation. Industrial crops and products. 31(1): 164-170.

Zegada-Lizarazu W, Zatta A, Monti A (2012) Water uptake efficiency and above-and belowground biomass development of sweet sorghum and maize under different water regimes. Plant and Soil. 351(1-2): 47-60. 